\title{
Judicial DEFERENCE IN BRAZIL AND In THE UNITED STATES OF AMERICA: A comparative overview
}

\author{
Fernanda Duarte* \\ Estácio de Sá University, Brazil \\ Rafael Mario Iorio Filho** \\ Estácio de Sá University, Brazil
}

As part of our research interest, applying the semiolinguistic methodology of discourse analysis and the method of comparison by difference, the latter borrowed from Antropology, we aim to provide a description of native and /or theoretical categories of the Brazilian legal culture in contrast with American legal culture, in order illuminate the idea that legal systems cannot be translated or verted straightforwardly as if it were a mere lexicon translation challenge. There is much more about it that relates to meaning and understanding that surpass the linguistic problem. That is what we intend to convey with our effort. On this presentation we will describe the Brazilian system whereas our colleague Prof. Ritchie will deal with the US model. So, the goal of both presentations is to discuss the different approach to judicial deference in Brazil's and the United State's legal systems - here considered as a cultural endeavor - taken by each country's Supreme Court.

It is necessary to say that we consider legal culture here as a very broad range category that tries to explain or describe how people in various historical and cultural contexts construct the meaning of law and how they use it in everyday life. 
Our theoretical framework is basically arranged according to three sets of ideas: 1) the understanding of law as a set of local discourses and practices; 2) the utility of the theoretical category "legal sensibilities" by Clifford Geertz"; 3) the recognition that culture interferes in socialization and social efficacy of Law when people translate legal categories.

The importance of this framework is that it leads us to the place of social relations and its web of meanings, helping us to appreciate the extent of the practices, rituals, and representations that directly impact law.

Thus, we allow ourselves to think that law is a cultural product, despite its universalist normative nature. If law can be taken as a branch of knowledge it must be interpreted in light of the "local knowledge". And this can work as a key concept to prevent uncritical transplantations of legal categories that ultimately are "misplaced" with low capacity to interfere with reality shaping people's behaviors.

In Brazil, especially from the argumentative point of view, this issue is a little shady because the possibility of judicial review of the discretionary administrative act swings between different ideas that go from a very narrow position that embodies a large degree of deference to broader ones that allow judges to re-evaluate the administrative act.

This variety does not allow the possibility of establishing standards of scrutiny (as it happens in the U.S. system, when the Supreme Court deals with equal protection claims, for instance). And all of them are used by the Supreme Court, as well as lowest courts to a certain extent. So there is no prevailing doctrine on the subject. And how can one know beforehand what is the prevailing position? The answer is simple: one cannot.

\footnotetext{
* PhD in Law. Professor of the Postgraduate Program in Law at Estácio de Sá University. Coordinator of CRN01 / LSA. Coordinator of the Center for Studies on Law, Citizenship, Process and Discourse / NEDCPD-PPGD / UNESA. Associate Professor at Fluminense Federal University / Faculty of Law. Researcher at NEPEAC / INCTInEAC - Institute for Comparative Studies in Institutional Conflict Management / PROPPi / UFF. Email: fduarte1969@yahoo.com.br

**PhD in Law. Professor of the Postgraduate Program in Law at Estácio de Sá University. Coordinator of the Center for Studies on Law, Citizenship, Process and Discourse / NEDCPD-PPGD / UNESA. CRN01 / LSA Coordinator. Professor at Fluminense Federal University / Faculty of Law. Researcher at NEPEAC / INCT-InEAC - Institute for Comparative Studies in Institutional Conflict Management / PROPPi / UFF. Email: rafa.ioriofilho@gmail.com

${ }^{1}$ Clifford Geertz, Local Knowledge: Further Essays in Interpretive Anthropology (Basic Books, 1983).
} 
The narrowest position states that discretion implies a choice that can only be made by the executive agents, but if it is found a misuse of power, the Judiciary has the authority to exam the choice that was made in deviation of its objective, as we can see in STF, AI-AgR/BA 594.955-1 (DJU Aug. 03, 2007), for instance.

On the other hand, the broader holdings state that the Judicial Branch has the duty to see if the constitutional principles were observed by the executive agents, as we can see in STF, ACO 876 MC-AgR/BA (DJU Aug. 01, 2008) and STF, ADPF 101/DF (DJU June 04, 2012).

Or we can call attention to STF, ADPF 378 MC/DF (DJU Mar. 08, 2016) when the Court has examined if the proceedings to impeach the President of the Republic under Law $1079 / 1950$ were legitimate, if the legal text was interpreted appropriately, in the light of the current Constitution.

Actually, some authors have even listed a different range of positions taken by the court. In a study of 2015, França ${ }^{2}$ has listed five situations:

1. The syndicability of administrative merit is not simply accepted. ${ }^{3}$

2. The Court uses control of administrative merit when it comes to mere control of legality. ${ }^{4}$

3. A control of the indirect administrative merit is made, without assuming frontally that it accomplishes it, trying to preserve the maximum of the constitutional principles, by means of an exercise of ponderation of involved values. $^{5}$

4. The control of administrative merit is accepted on a regular basis and in exceptional cases. ${ }^{6}$

5. The control of administrative merit is removed because of the inadequacy of the procedural means used in the exercise of the jurisdictional claim. ${ }^{7}$

\footnotetext{
${ }^{2}$ Gil França, O controle dos atos administrativos e a jurisprudência do STJ e do STF. EMPÓRIO DO DIREITO (Sept. 24, 2015).

${ }^{3}$ STF, AgR in RE 480.107 (DJe Mar. 27, 2009).

${ }^{4}$ STF, HC 82.893/SP (DJ Apr. 08, 2005).

${ }^{5}$ STF, AI 509.213 in AgR/AL (DJ Dec. 16, 2005); STF, RMS 24.823/DF (DJ May 19, 2006).

${ }^{6}$ STF, RMS 24.699/DF (DJ July 01, 2005).

${ }^{7}$ STF, Ag in RE 505.439/MA (DJe Aug. 28, 2008).
} 
And even some Brazilian Justices, who are called Ministros, in some of the cases decided by the Court, can adopted more than one position regarding the possibility of judicial review of administrative acts which will have an impact in the way judicial deference is perceived as well.

In a way, from these cases we can see a lack of a standardization awareness by the Brazilian Supreme Court (which one might say is one of the features of Brazil's legal system). And this turns the subject of judicial deference even more problematic once predictability is not a card we can play easily or safely.

And we can say that the meaning and uses of judicial deference differ radically between the Brazilian and U.S. legal cultures. The two Supreme Courts view separation of powers, constitutional supremacy, the role of the judiciary, and the use of discretion very differently. In short, the Brazilian Supreme Court is led by the motto "We know better!" while the U.S. Supreme Court might respond "You decide!".

\section{REFERENCE LIST}

A. S. de M. Godoy, Direito administrativo nos EUA preserva poder público. REVISTA CONSULTOR JURÍDICO (June 07, 2011), https://www.conjur.com.br/2011-jun-07/nao-direitoabsoluto-acao-administracao-eua?pagina=3.

C. Tácito, Presença norte-americana no direito administrativo brasileiro, 129 REVISTA DE DIREITO ADMINISTRATIVO RDA, 21-33, (July/Sept. 1977) http://bibliotecadigital.fgv.br/ojs/index.php/rda/article/view/42480/41199.

C. GeERTZ, Local KNOWLEdGe: Further Essays in InTERPRETIVE ANTHRopology (Basic Books, 1983).

G. França, $O$ controle dos atos administrativos e a jurisprudência do STJ e do STF. EMPÓRIO DO DIREITO (Sept. 24, 2015), http://emporiododireito.com.br/leitura/o-controle-dos-atosadministrativos-e-a-jurisprudencia-do-stj-e-do-stf.

H. Berman, Law and Revolution: The Formation of the Western Legal Tradition (Harvad University Press, 1983). 
R. C. R. Oliveira, O Modelo Norte-Americano de Agências Reguladoras e sua Recepção pelo Direito Brasileiro. 12 REVISTA DA EMERJ, (47) 157-176 (2009) http://www.emerj.tjrj.jus.br/revistaemerj_online/edicoes/revista47/Revista47_157.pdf

\section{CASES}

Supremo Tribunal Federal (STF), AI-AgR/BA 594.955-1 (DJU Aug. 03, 2007).

STF, HC 82.893/SP (DJ Apr. 08, 2005).

STF, RMS 24.699/DF (DJ July 01, 2005).

STF, AI 509.213 in AgR/AL (DJ Dec. 16, 2005).

STF, RMS 24.823/DF (DJ May 19, 2006).

STF, ACO 876 MC-AgR/BA (DJU Aug. 01, 2008).

STF, AgR in RE 480.107 (DJe Mar. 27, 2009).

STF, ADPF 101/DF (DJU June 04, 2012).

STF, ADPF 378 MC/DF (DJU Mar. 08, 2016).

STF, Ag in RE 505.439/MA (DJe 28 Aug. 28, 2008)

Submetido em: 17/07/2019

Aceito em: 05/08/2019 